\title{
Analisis musim penangkapan ikan cakalang di perairan Kepala Burung, Papua
}

\author{
Analysis of skipjack fishing season in Kepala Burung waters, Papua
}

MURNIATI TILIK*, JOHNNY BUDIMAN dan JOHNY WENNO

Program Studi Pemanfaatan Sumberdaya Perikanan, Fakultas Perikanan dan Ilmu Kelautan, Universitas Sam Ratulangi, Manado 95115

\begin{abstract}
Knowledge of the pattern of fishing season is one of important factors in exploitation activities of skipjack resource, particularly in determining the right time to increase the intensity of fishing as well as to determine the right time to reduce the intensity of the fishing. This study aimed to know the tendency of catch per unit fishing effort (CPUE) of skipjack per month; and to determine the patterns of skip jack fishing season in the region of Kepala Burung with CPUE approach. The pattern of the fishing season was analyzed using the Average Percentage Methods based on the Times Series Analysis. In 2014, the number of pole and line vessels operating in the waters of the Kepala Burung and are ported in the city of Sorong was 31 units. Based on monthly catch and number of trips, the CPUE was calculated and then the fishing season was analyzed. Index of fishing season (IM) greater than 100 are in the months of April, May, and September to December. So, annually fishing season occurred twice and the peaks were in April and November, while the poorest season occurred in January and July.
\end{abstract}

Keywords: skipjack, CPUE, the Average Percentage Methods, Sorong, Papua

\begin{abstract}
ABSTRAK
Pengetahuan mengenai pola musim penangkapan merupakan salah satu faktor penting dalam kegiatan eksploitasi sumberdaya cakalang, terutama dalam menetapkan waktu yang tepat untuk meningkatkan intensitas penangkapan sekaligus menentukan waktu yang tepat pula untuk mengurangi intensitas penangkapan. Penelitian ini bertujuan untukb mengetahui kecenderungan hasil tangkapan per satuan upaya penangkapan (CPUE) ikan cakalang setiap bulan; dan untuk menentukan pola musim penangkapan ikan cakalang di perairan Raja Ampat dengan pendekatan CPUE. Analisis pola musim penangkapan ikan menggunakan Metode Persentase Rata-rata (the Average Percentage Methods) yang didasarkan pada Analisis Runtun Waktu (Times Series Analysis). Jumlah kapal pole and line yang beroperasi di perairan Kepala Burung dan berpangkalan di Kota Sorong sampai dengan tahun 2014 berjumlah 31 buah. Dari hasil tangkapan dan jumlah trip setiap bulan, kemudian dihitung CPUE dan selanjutnya dilakukan analisis musim penangkapan. Indeks Musim (IM) yang lebih besar dari 100 terdapat pada bulan-bulan April, Mei dan September sampai dengan Desember. Jadi dalam satu tahun terjadi dua kali musim penangkapan dengan puncak pada bulan April dan pada bulan November, sedangkan puncak musim paceklik terjadi pada bulan Januari dan bulan Juli.
\end{abstract}

Kata-kata kunci: cakalang, CPUE, Metode Persentase Rata-rata, Sorong, Papua

\section{PENDAHULUAN}

Ikan cakalang (Katsuwonus pelamis) tergolong sumberdaya perikanan pelagis penting dan merupakan salah satu komoditi ekspor non-migas. Ikan cakalang terdapat hampir di seluruh perairan Indonesia, terutama di bagian timur Indonesia.

\footnotetext{
*Penulis untuk penyuratan; email: murniatitilik@yahoo.com
}

Ikan cakalang merupakan salah satu jenis ikan pelagis besar yang potensil, bernilai ekonomis tinggi sehingga banyak dimanfaatkan oleh nelayan dengan menggunakan berbagai macam alat tangkap dan tingkat teknologi yang bervariasi seperti huhate (pole and line), pancing tangan (hand line), pancing tonda (trolling line), pukat cincin (purse seine) dan kadang jaring insang permukaan (surface gill net), di mana dalam 